\title{
INTERCROPPING PERIOD BETWEEN SPECIES OF GREEN MANURES AND ORGANICALLY-FERTILIZED COFFEE PLANTATION
}

\author{
Rosileyde Gonçalves Siqueira Cardoso ${ }^{1}$, Adriene Woods Pedrosa ${ }^{2}$, Mateus Cupertino Rodrigues ${ }^{3}$, \\ Ricardo Henrique Silva Santos ${ }^{4}$, Hermínia Emília Prieto Martinez ${ }^{5}$, Paulo Roberto Cecon ${ }^{6}$
}

(Received: October 6, 2016; accepted: Tuesday, May 2, 2017)

\begin{abstract}
The adequate supply of nitrogen to coffee plantation is one of the main challenges of organic agriculture. The aim of the present study was to evaluate the effect of organic fertilization with two legume species in different intercropping periods on nitrogen nutrition, initial growth and productivity of coffee plantation. The experimental design was in randomized blocks, in 2x4 split-plot factorial design, being that the plot consisted of two intercrops (coffee+jack bean and coffee+hyacinth bean) and the four intercropping periods (30,60, 90 and 120 days after sowing of the legume), and the subplot by $50 \%$ and $100 \%$ of fertilization for the coffee plantation. The increase in the intercropping period between legumes and coffee plantation favored a greater increase in height and node number of coffee trees, besides showing higher heights when fertilized with $50 \%$ of the recommended dose and intercropped with hyacinth bean. The intercropping with the hyacinth bean resulted in a larger crown diameter of coffee trees in 2010 and a larger diameter accumulated in the two evaluated years. Higher $\mathrm{N}$ contents were found in coffee trees fertilized with $100 \%$ of the recommended dose. The legumes supplied the nutritional requirements of the coffee harvest fertilized with $50 \%$ of the dose. The bean yield of the processed coffee is not affected by the intercropping with the green manures of jack bean or hyacinth bean.
\end{abstract}

Index terms: Coffea arabica cv. Oeiras, Canavalia ensiformis, Dolichos lablab, nitrogen cycling, organic fertilization.

\section{PERÍODO DE CONSORCIAÇÃO ENTRE ESPÉCIES DE ADUBOS VERDES E CAFEEIROS ADUBADOS ORGANICAMENTE}

RESUMO: O suprimento adequado de nitrogênio aos cafeeiros é um dos principais desafios da agricultura orgânica. O trabalho objetivou avaliar o efeito da adubação orgânica com duas espécies de leguminosas em diferentes períodos de consorciação sobre a nutrição nitrogenada, o crescimento e a produtividade iniciais de cafeeiros. O delineamento foi em blocos casualizados, em esquema fatorial $(2 \times 4)$ com parcela subdividida, sendo a parcela constituída por dois consórcios entre cafeeiros e leguminosas (café+feijão-de-porco e café+lablabe) e os 4 períodos de consorciação (30, 60, 90 e 120 dias após a semeadura da leguminosa), e a subparcela por $50 \%$ e $100 \%$ da adubação para o cafeeiro. O aumento do período de consorciação entre leguminosas e cafeeiros favoreceu um maior incremento em altura e do número de nós dos cafeeiros, e estes apresentaram maiores alturas quando fertilizados com $50 \%$ da dose recomendada e consorciados com lablabe. A consorciação com a lablabe resultou em maior diâmetro de copa dos cafeeiros em 2010 e maior diâmetro acumulado nos dois anos avaliados. Maiores teores de $\mathrm{N}$ foram encontrados nos cafeeiros adubados com $100 \%$ da dose recomendada. As leguminosas complementaram e supriram as necessidades nutricionais exigidas na colheita do café adubado com $50 \%$ da dose. O rendimento de grão do cafeeiro beneficiado não é prejudicado pelo consórcio com os adubos verdes feijão-de-porco ou lablabe.

Termos para indexação: Coffea arabica cv. Oeiras, Canavalia ensiformis, Dolichos lablab, ciclagem de nitrogênio, adubação orgânica.

\section{INTRODUCTION}

Chemical fertilizer increases the cost of crop yield and favors the growing demand for biological and renewable origin inputs. Therefore, nutrient cycling in coffee nutrition is becoming increasingly important. In this sense, it is important to study nutritional alternatives aimed to reduce costs and dependence on industrial inputs, without implying significant losses of coffee productivity and quality (VILELA et al., 2011).
Nitrogen from fertilizers applied to the soil can be recovered by the root and shoot systems of the plants or remain in the soil, where it can be immobilized or lost from the soil-plant system (FENILLI et al., 2008), i.e., the efficiency of nitrogen fertilizers is associated with their soil dynamics (PEDROSA et al., 2014). The ability of the coffee tree to acquire nutrients depends on how the nutrient was applied (by organic or mineral), the efficiency of absorption mechanisms and the volume of soil explored by the roots, i.e.,

\footnotetext{
${ }^{1}$ Federal University of Viçosa/UFV - Avenue Getúlio Vargas no 55 apt ${ }^{\circ} 601$ - Centro - 36.880-000 - Muriaé - MG rsiqueiracardoso@gmail.com

${ }^{2}$ Agricultural Research Company of Minas Gerais/EPAMIG - Campus UFV - Cx. P. 216 - 36.571-000 - Viçosa - MG awoodsp74@gmail.com

3,4,5Federal University of Viçosa/UFV - Plant Science Department - Avenue PH Rolfs - 36.570-000 - Viçosa - MG mateusagroufv1987@gmail.com, rsantos@ufv.br, herminia@ufv.br

${ }^{6}$ Federal University of Viçosa/UFV - Statistics Department - Avenue PH Rolfs - 36.570-000 -Viçosa - MG - cecon@ufv.br
} 
the plant's ability to grow and produce well with certain nutrient content of the soil, called use efficiency (AMARAL et al., 2011).

The alternative production pathways aimed at reducing the use of external inputs should be economically viable, being a promising alternative the use of legume phytomass, by reducing some negative effects of continuous monoculture of the soil (ILANY et al., 2010). Moreover, supply of nitrogen in sufficient amounts to crops is one of the main challenges for organic coffee growing because, according to Guimarães et al. (1999), it is necessary to apply $300 \mathrm{~kg} \mathrm{ha}^{-1}$ year $^{-1} \mathrm{~N}$ to produce 60 bags ha $^{-1}$, approximately.

Green manures contribute to the nutrient cycling, both those added by fertilizers and not utilized by the main crop, as well as those from the organic matter $(\mathrm{OM})$ mineralization of the soil (TORRES; PEREIRA; FABIAN, 2008). Nitrogenfixing legumes can be used as a source of $\mathrm{N}$ for coffee crop because their cultivation between the lines of coffee tree allows recycling nutrients by the decomposition of the produced biomatter, as well as the contribution of the OM to the soil. However, organic fertilizers regulated by organic legislation such as manures, organic compounds, bran, meals, among others (RICCI et al., 2005), present a low $\mathrm{N}$ concentration from approximately 10 to $50 \mathrm{~g} \mathrm{~kg}^{-1}$, besides mineralization and complex behavior in the soil.

The nutrient mineralization of green manures should be synchronized as a period of increased nutritional demand of the coffee tree. High mineralization rates before or after this period can promote loss or immobilization of $\mathrm{N}$, with few benefits to the crop. In addition, the growth of green manure may affect the growth and yield of coffee plantation. Therefore, the accumulation of nutrients and the $\mathrm{N}$ contribution from the green manures should be associated with the choice of the planting and cutting periods. Therefore, flowering is probably not a good indicator of the cutting season of green manures, since the species flowers at different times under different weather conditions, as well as different mass accumulations in different phenological stages and nutritional demand of coffee trees.

The aim of the present study was to evaluate the influence of the cutting season of legumes jack bean (Canavalia ensiformis (L.) DC.) and hyacinth bean (Dolichos lablab L.) and organic fertilization on the nutritional status of $\mathrm{N}$, growth and the initial yield of coffee trees.

\section{MATERIAL AND METHODS}

The experiment was carried out from October 2007 to May 2011 at the Horta Velha experimental field of the Universidade Federal de Viçosa, in Viçosa, MG, Brazil, located at $20^{\circ} 45^{\prime} 14^{\prime \prime} \mathrm{S}$ and $42^{\circ} 52^{\prime} 53^{\prime \prime} \mathrm{W}$, and $650 \mathrm{~m}$ altitude. The chemical characterization of the soil before planting and in subsequent years is presented in Table 1.

The experimental design was in randomized blocks, in a $((2 \times 4)+1) \times 2$ split-plot factorial design with five replicates. The plot consisted of two intercrops between coffee and legumes (coffee+jack bean and coffee+hyacinth bean) and four intercropping periods $(30,60,90$ and 120 days after sowing of the legume - DASL), besides a treatment without intercropping, with legumes as a control. The subplot was composed by fertilization with $50 \%$ and $100 \% \mathrm{~N}$ dose for the coffee growing. Each subplot consisted of six useful plants.

The transplanting of $C$. arabica cv. Oeiras seedlings was performed in October 2007, spaced $2.80 \mathrm{~m}$ between lines and $0.75 \mathrm{~m}$ between plants. The coffee was fertilized based on the recommendations of Guimarães et al. (1999), receiving the subplots with $50 \%$ and $100 \%$ fertilization, respectively (Table 2). The chemical analysis results of the materials used in fertilization are presented in Table 3.

The legumes jack bean (JB) and hyacinth bean (HB) were previously inoculated with the rhizobia strains Bradyrhizobium sp. and Bradyrhizobium elkanii, respectively, and sown in three lines between the coffee lines, at $1 \mathrm{~m}$ from the coffee trees, spaced $0.4 \mathrm{~m}$ apart and at the density of six seeds per linear meter. The legumes were cut according to the treatments, and the residues were placed under the canopy of the coffee tree.

Evaluations of coffee vegetative development were performed at the end of the phases of major (March) and minor (September) growth. These data were presented as increment in the period, i.e., the growth of the end date (March 2010) minus the growth of the initial date (September 2009), and the final increment as the sum of the 2009 and 2010 increments.

For evaluation of plant height $(\mathrm{PH}, \mathrm{cm})$, a measuring tape was placed parallel to the orthotropic branch of the coffee tree, measuring from the soil surface to the apical bud. 
TABLE 1 - Results of routine soil chemical analysis of the experimental area, before the implementation of treatments in October 2007, in the layer 00-20 cm and 20-40 cm, and in the following years, Oct 2008 and Oct 2009 , in the layer $00-20 \mathrm{~cm}$.

\begin{tabular}{|c|c|c|c|c|c|c|c|c|c|c|c|c|c|c|}
\hline \multirow{2}{*}{$\begin{array}{l}\text { Year } \\
2007 \\
\end{array}$} & \multirow{2}{*}{$\begin{array}{c}\text { Treat } \\
00-20\end{array}$} & \multirow{2}{*}{$\begin{array}{c}\mathbf{p H} \\
\mathbf{H}_{2} \mathbf{O} \\
6,0\end{array}$} & \multicolumn{2}{|c|}{$\begin{array}{l}\text { P } \quad \text { K } \\
\mathbf{m g ~ d m}^{-3}\end{array}$} & \multirow{2}{*}{$\begin{array}{l}\mathbf{C a}^{2+} \\
2,0\end{array}$} & \multirow{2}{*}{$\begin{array}{l}\mathbf{M g}^{2+} \\
0,7\end{array}$} & \multirow{2}{*}{$\begin{array}{c}\mathbf{A \mathbf { l } ^ { 3 + }} \\
0,0\end{array}$} & \multicolumn{2}{|c|}{$\begin{array}{l}\mathrm{H}+\mathrm{Al} \quad \mathrm{EB} \\
\mathrm{cmol}_{\mathrm{c}} \mathbf{d m}^{-3}\end{array}$} & \multirow{2}{*}{$\begin{array}{l}\text { CEC(t) } \\
2,88\end{array}$} & \multirow{2}{*}{$\begin{array}{l}\text { CEC(T) } \\
6,84 \\
\end{array}$} & \multicolumn{2}{|c|}{$\begin{array}{c}\text { V m } \\
\%\end{array}$} & \multirow{2}{*}{$\begin{array}{l}\begin{array}{l}\text { P-rem } \\
\text { mg L }^{-1}\end{array} \\
24,2 \\
\end{array}$} \\
\hline & & & 14,8 & 69 & & & & 3,96 & 2,88 & & & 42 & 0 & \\
\hline & $20-40$ & 5,6 & 4,4 & 36 & 1,1 & 0,4 & 0,0 & 3,14 & 1,59 & 1,59 & 4,73 & 34 & 0 & 21,0 \\
\hline \multirow[t]{9}{*}{2008} & JB30 & 7,0 & 149,9 & 210 & 4,8 & 1,5 & 0,0 & 0,83 & 6,84 & 6,84 & 7,67 & 89 & 0 & \\
\hline & JB60 & 6,4 & 105,3 & 170 & 3,7 & 1,3 & 0,0 & 1,65 & 5,43 & 5,43 & 7,08 & 77 & 0 & \\
\hline & JB90 & 6,9 & 127,7 & 162 & 4,3 & 1,5 & 0,0 & 0,99 & 6,21 & 6,21 & 7,20 & 86 & 0 & \\
\hline & JB120 & 6,6 & 85,8 & 124 & 3,4 & 1,2 & 0,0 & 1,49 & 4,92 & 4,92 & 6,41 & 77 & 0 & \\
\hline & HB30 & 6,9 & 102,4 & 172 & 4,2 & 1,4 & 0,0 & 1,32 & 6,04 & 6,04 & 7,36 & 82 & 0 & \\
\hline & HB60 & 6,9 & 73,3 & 182 & 4,2 & 1,4 & 0,0 & 0,99 & 6,07 & 6,07 & 7,06 & 86 & 0 & \\
\hline & HB90 & 6,8 & 117,7 & 132 & 3,9 & 1,4 & 0,0 & 1,15 & 5,64 & 5,64 & 6,79 & 83 & 0 & \\
\hline & HB120 & 6,7 & 105,3 & 124 & 3,8 & 1,4 & 0,0 & 1,32 & 5,52 & 5,52 & 6,84 & 81 & 0 & \\
\hline & TEST & 7,1 & 201,7 & 210 & 5,3 & 1,5 & 0,0 & 0,99 & 7,34 & 7,34 & 8,33 & 88 & 0 & \\
\hline \multirow[t]{9}{*}{2009} & JB30 & 6,4 & 11,8 & 97 & 2,4 & 1,0 & 0,0 & 1,98 & 3,65 & 3,65 & 5,63 & 65 & 0 & \\
\hline & JB60 & 6,3 & 17,4 & 59 & 2,1 & 0,9 & 0,0 & 2,31 & 3,15 & 3,15 & 5,46 & 58 & 0 & \\
\hline & JB90 & 6,9 & 74,1 & 93 & 2,7 & 1,0 & 0,0 & 1,65 & 3,94 & 3,94 & 5,59 & 70 & 0 & \\
\hline & JB120 & 6,4 & 19,5 & 54 & 2,1 & 0,9 & 0,0 & 2,64 & 3,14 & 3,14 & 5,78 & 54 & 0 & \\
\hline & HB30 & 6,6 & 24,6 & 83 & 2,6 & 1,0 & 0,0 & 2,31 & 3,81 & 3,81 & 6,12 & 62 & 0 & \\
\hline & HB60 & 6,6 & 20,0 & 97 & 2,3 & 1,0 & 0,0 & 1,98 & 3,55 & 3,55 & 5,53 & 64 & 0 & \\
\hline & HB90 & 7,0 & 52,6 & 113 & 2,8 & 1,0 & 0,0 & 1,82 & 4,09 & 4,09 & 5,91 & 69 & 0 & \\
\hline & HB120 & 6,7 & 27,0 & 71 & 2,3 & 0,8 & 0,0 & 1,82 & 3,28 & 3,28 & 5,10 & 64 & 0 & \\
\hline & TEST & 6,6 & 17,9 & 72 & 2,3 & 0,9 & 0,0 & 2,64 & 3,38 & 3,38 & 6,02 & 56 & 0 & \\
\hline \multicolumn{7}{|c|}{$\mathrm{pH}$ of water, $\mathrm{KCl}$ and $\mathrm{CaCl} 2-1: 2.5$ ratio } & \multicolumn{7}{|c|}{ CEC (t) - Effective cation exchange capacity } & \\
\hline \multicolumn{7}{|c|}{$\mathrm{P}-\mathrm{K}-$ Mehlich 1 extractor } & \multicolumn{7}{|c|}{ CEC $(\mathrm{T})$ - Cation Exchange capacity at $\mathrm{pH} 7,0$} & \\
\hline \multicolumn{7}{|c|}{$\mathrm{Ca}-\mathrm{Mg}-\mathrm{Al}-$ Extractor $: \mathrm{KCL}-1 \mathrm{~mol} \mathrm{~L}^{-1}$} & \multicolumn{4}{|c|}{$\mathrm{V}=$ Base saturation index } & & & & \\
\hline \multicolumn{8}{|c|}{$\mathrm{H}+\mathrm{Al}-0,5 \mathrm{~mol} \mathrm{~L}^{-1}$ calcium acetate extractor $-\mathrm{pH} 7,0 \mathrm{~m}$} & \multicolumn{6}{|c|}{$\mathrm{m}=$ Alumínio saturation index } & \\
\hline \multicolumn{8}{|c|}{$\mathrm{EB}=$ Exchangeable bases } & rem $=$ & osph & rus Rem & & & & \\
\hline
\end{tabular}

For evaluation of crown diameter (CD, cm), a measuring tape was placed transversely to the orthotropic branch in relation to interline of the coffee tree, measuring the higher distance between the first pair of leaves present in the opposite plagiotropic branches. It was also quantified the number of total nodes (NTN) in a plagiotropic branch in the middle third of the plant. In 2009, the branches chosen in 2008 occupied the lower third of the plant, being replaced by other branches in its middle third. The leaf nitrogen concentration (NC) in coffee plantation was determined in November and March of the years 2008/2009 and 2009/2010 at 30 and 150 DASL, in leaf samples of the 3rd and 4th pairs of the plagiotropic branch present in the middle third of the coffee tree.

The legumes were cut at ground level in a linear area of $1,0 \mathrm{~m}$, and according to the proposed treatments and managements, this sample was weighed and the subsamples were removed. The subsamples were washed in deionized water and dried in a convection oven at $70{ }^{\circ} \mathrm{C}$ until constant weight and stored for further determination of $\mathrm{N}$ concentration by sulfur digestion, according to Kjeldahl methodology modified by Cotta et al. (2007). Productivity was determined by discounting the area occupied by coffee plantation. 
TABLE 2 - Fertilization performed in coffee plantation in the 2008/2009 and 2009/2010 crop years.

\begin{tabular}{|c|c|c|c|c|c|}
\hline \multirow{2}{*}{\multicolumn{2}{|c|}{ Fertilization ${ }^{1}$}} & Limestone & Thermophosphate & Poultry litter & $\begin{array}{c}\text { Castor bean } \\
\text { cake }\end{array}$ \\
\hline & & \multicolumn{2}{|c|}{--------- g plant ${ }^{-1}$---------- } & \multicolumn{2}{|c|}{------- g DM plant ${ }^{-1}$} \\
\hline \multirow{7}{*}{ Mulch } & Planting & 50.00 & 300.00 & 750.00 & --- \\
\hline & (Dec/Jan 2008) & --- & --- & $325.00^{2}$ & --- \\
\hline & $\begin{array}{c}1 \text { st year } \\
(2008 / 2009)\end{array}$ & --- & -- & $653.25^{3}$ & --- \\
\hline & \multirow{4}{*}{$\begin{array}{c}\text { 2nd year } \\
(2009 / 2010)\end{array}$} & --- & --- & --- & 304.85 \\
\hline & & --- & --- & 1044.00 & --- \\
\hline & & --- & --- & --- & 383.24 \\
\hline & & --- & --- & --- & 304.70 \\
\hline
\end{tabular}

${ }^{1}$ Values calculated considering the recommendation of $300 \mathrm{~kg} \mathrm{ha}^{-1}$ year ${ }^{-1} \mathrm{~N}$ (GUIMARÃES et al., 1999);

${ }^{2}$ Applied in two side dressing; ${ }^{3}$ Applied in three side dressing.

TABLE 3 - Chemical analysis results of poultry litter (PL) and castor bean cake (CBC) used in basal fertilization of coffee plantation in 2007 and topdressing fertilization in the following years, 2008 and 2009.

\begin{tabular}{|c|c|c|c|c|c|c|c|c|c|c|c|c|c|c|c|c|}
\hline Year & & $\mathbf{N}$ & $\mathbf{Y}$ & $\mathbf{K}$ & $\mathrm{Ca}$ & Mg & $\mathbf{Y}$ & $\begin{array}{l}\text { CO } \\
(\%)\end{array}$ & $\mathbf{C} / \mathbf{N}$ & $\mathbf{Z n}$ & $\mathbf{F e}$ & Mn & $\mathbf{C u}$ & B & $\begin{array}{c}\text { pH } \\
\mathrm{H}_{2} \mathrm{O}\end{array}$ & $\begin{array}{c}\text { Moisture } \\
(\%)\end{array}$ \\
\hline $2007 / 08$ & PL & 2.73 & 1.99 & 1.47 & 2.84 & 0.55 & 0.38 & 21.05 & 8.98 & 461 & 1413 & 369 & 56 & 87.7 & 7.02 & 53 \\
\hline $2008 / 09$ & PL & 1.99 & 1.44 & 2.88 & 3.53 & 0.64 & 0.40 & 20.74 & 10.42 & 536 & 2601 & 638 & 63 & 65.3 & 7.69 & 60 \\
\hline $2009 / 10$ & $\mathrm{CM}$ & 5.85 & 0.61 & 0.88 & 1.64 & 0.47 & 0.55 & 15.75 & 2.69 & 120 & 9355 & 216 & 23 & 26.6 & 5.91 & 12.9 \\
\hline & PL & 1.82 & 2.90 & 1.84 & 12.23 & 0.56 & 0.79 & 8.11 & 4.45 & 743 & 1858 & 503 & 63 & 54.4 & 7.00 & 42 \\
\hline
\end{tabular}

The coffee yield was evaluated in the harvests performed in March 2010 and May 2011 in all the useful plants in the subplots. The fruits were harvested and weighed, obtaining the cherry coffee yield. The samples were collected and the fruits were dried in a terrace up to $12 \%$ moisture, yield data on the coconut coffee $\left(\mathrm{kg} \mathrm{ha}^{-1}\right)$, which were then processed and obtained the processed bean yield $\left(\mathrm{kg} \mathrm{ha}^{-1}\right)$, and the percent yield $(\%)$. The productivity $\left(60 \mathrm{bg} \mathrm{ha}^{-1}\right)$ of each year and the average biannual productivity (bg ha ${ }^{-1}$ ) were determined with the average productivity of 2010 and 2011.

The data were evaluated through analysis of variance by F test, followed by Dunnett's test (for comparisons with the control) or Tukey test (for comparisons in the factorial), or even by regression analysis of variance, when pertinent, always at 5\% probability level. The analyses were performed using the System for Statistical and Genetic Analyses - SAEG (FUNDAÇÃO
ARTHUR BERNARDES, 2007). The choice of the regression models was made based on the biological phenomenon, the determination coefficient and the residue analysis at 5\% probability level.

\section{RESULTS AND DISCUSSION}

In the 2009/2010 season, there was effect of the interaction between species and the legume intercropping period on the growth of jack bean and hyacinth bean, justified because the growth of the species were directly related to the growth habit and duration in the field. The accumulation of fresh (FM) and dry matter (DM) in both species increased until the end of the evaluated period, with fitting of quadratic regression models (Figures 1A and B). Such model is because the maximum evaluated period is 90 days, in which the species are at the growth peak and there wasn't mass losses due to the decreased vegetative part as a function of the flowering. 
$\mathbf{A}$

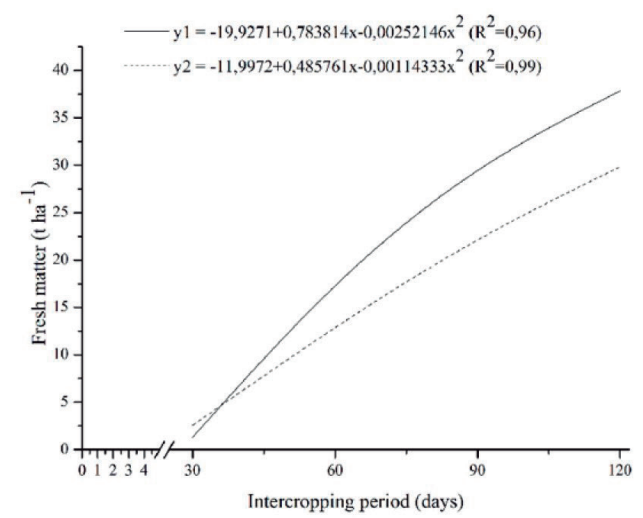

C



B

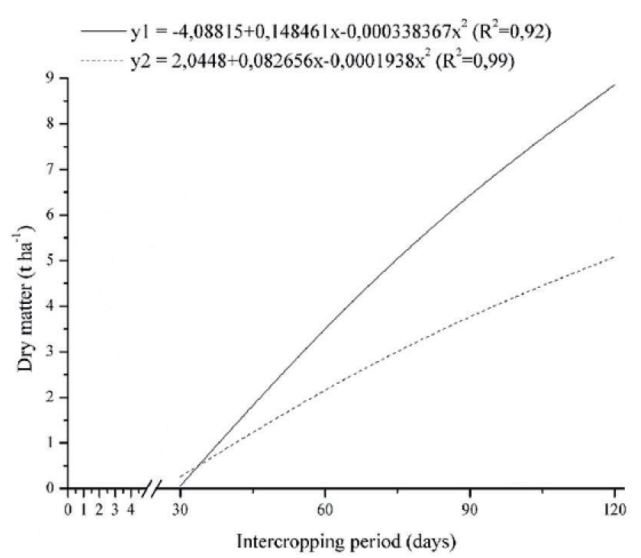

$\mathbf{D}$

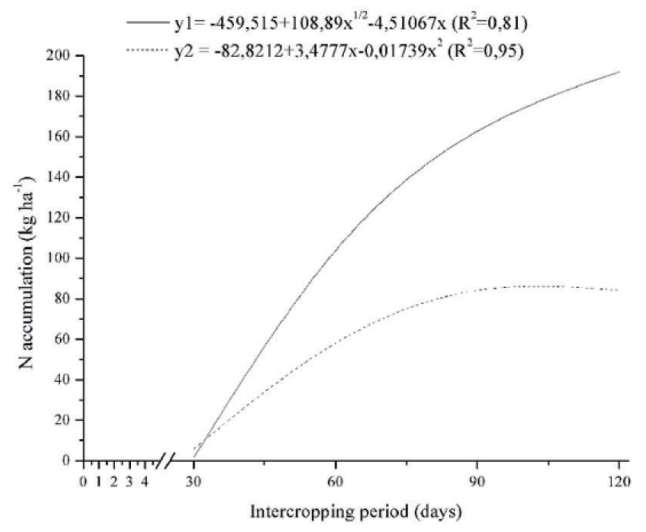

FIGURE 1 - Accumulation of fresh and dry matter ( $\mathrm{t} \mathrm{ha} \mathrm{h}^{-1}$, A and $\mathrm{B}$, respectively), concentration (NC \%, C) and accumulation of nitrogen (NAC kg ha $\left.{ }^{-1}, \mathrm{D}\right)$ in the green manures jack bean (y1) and hyacinth bean (y2) intercropped with coffee trees in 2009/2010.

Jack bean accumulated more mass than hyacinth bean, mainly from 90 DASL, and there was no significant difference ( $\mathrm{p} \geq 0.05$ ) between the species in the 30 and 60 DASL periods. This fact is due to the physical characteristics of the species, which can be better distinguished from 60 days, when the stem/leaf ratio of jack bean is increased, thus accumulating more mass.

The DM content in the jack bean was higher than the hyacinth bean at the same cutting dates, probably due to its shorter development cycle, with pod formation already at 90 days, thus increasing its DM content from this date. No flower and hence pod formation were observed in the hyacinth bean until the 120 DASL, the last cutting date. In a study on the intercropping between organic coffee trees and jack bean and hyacinth bean, it was also reported in the first experimental year that the DM accumulation by the jack bean was superior to hyacinth bean, $2.65 \mathrm{t}$ $\mathrm{ha}^{-1}$ and $1.89 \mathrm{t} \mathrm{ha}^{-1}$, respectively (MOREIRA et al., 2014), indicating that there is consistency of the result obtained with those found by other authors.

The jack bean showed higher NC in relation to the hyacinth bean at 60,90 and 120 DASL. The $\mathrm{NC}$ in the hyacinth bean decreased over time. With the jack bean happened the opposite, where the NC was increased up to 70 DASL (inflection point), when it went down to the last cutting date (Figure 1C). 
The nitrogen accumulation (NAC) in jack bean increased over time, totaling $192 \mathrm{~kg} \mathrm{ha}^{-1} \mathrm{~N}$ at 120 days (Figure 1D). The NAC in the jack bean was superior to the hyacinth bean, except at 30 DASL. The highest NAC by hyacinth bean occurred at 100 days, with $91.05 \mathrm{~kg} \mathrm{ha}^{-1} \mathrm{~N}$. There is a report of lower NAC in jack bean $(71.52 \mathrm{~kg}$ $\mathrm{ha}^{-1}$ ) at $120 \mathrm{DASL}$, in an experiment performed in a lower altitude region and intercropped with adult coffee trees (MOREIRA et al., 2014). The weather conditions provided by the highest altitude and mainly the intercropping with younger coffee trees, providing low shade to the jack bean and allowing its full development due to its erect growth habit, resulted in lower competition between green manure and coffee tree, thus favoring the highest yield and NAC of the jack bean in the present experiment.

The $\mathrm{N}$ concentration is considered as adequate for coffee tree between 2.6 and $3.0 \%$. In order to reach such concentrations, it is necessary to apply approximately $300 \mathrm{~kg} \mathrm{ha}^{-1}$ per year of $\mathrm{N}$, with expected yield of $60 \mathrm{bags} \mathrm{ha}^{-1}$ (GUIMARÃES et al., 1999). The NAC in jack bean at 120 DASL would be enough to supply the nutritional demand in the first years or to supplement it in subsequent years, assuming that there would be no competition with the coffee tree.

The intercropping period with legumes showed an isolated effect on height and number of nodes of the coffee trees, both in 2009, probably because the development of legumes was more pronounced in relation to coffee tree in the early years, when their size was still low. Legumes influenced the crown diameter individually in 2010 and the final diameter (sum of the increments) in the years 2009 and 2010. The height of coffee trees in 2010 was influenced by interactions between species and intercropping, fertilization and species, and fertilization and intercropping. Therefore, it was observed that the crown and root development of the coffee tree created a competition between these and the green manures, directly influencing the growth of coffee trees. Moreover, there was effect of the interaction between fertilization and intercropping on the diameter and number of nodes in 2010, and the final number of nodes.

The height increase was lower with the increased intercropping period in 2009 (Figure 2A). In 2010, coffee trees intercropped jack bean overcame those with hyacinth bean only at 30 days, being similar in the other intercropping periods (Table 4 and Figure 2B). Vilela et al. (2011) verified that the coffee trees fertilized with legumes showed higher vegetative growth than those that received only nitrogen fertilization with ammonium sulfate, except for the plant height, which was statistically similar in all treatments at the end.

The intercropping between coffee trees and jack bean in 2010 resulted in a smaller height increase up to 70 DASL, while those intercropped with hyacinth bean showed a linear increasing height throughout the intercropping period (Figure 2B).

The hypothesis that the residual effect of green manures, nitrogen immobilized in 2008 and 2009 and subsequently released over time, favored culture of interest may explain the increment presented by height and crown diameter in 2010 , regardless of the applied dose (Figures $3 \mathrm{~A}$ and $3 \mathrm{~B})$, being that the longer the intercropping period with green manures, the higher these values.

Coffee trees intercropped with hyacinth bean and fertilized with $50 \% \mathrm{~N}$ dose showed a higher increment in height when compared to those fertilized with $100 \%$ dose. However, at the $100 \%$ dose there was no significant difference resulting from legume species (Table 4).

The coffee height increment in 2010, with $50 \%$ fertilization and intercropping for 30 DASL, was higher when compared to the $100 \%$ dose, and did not differ in the other intercropping periods in both doses. The height increment curves in 2010 in relation to the fertilization doses (Figure 3A) showed the same curve pattern of the species (Figure 2B), where for the $50 \%$ dose, the growth remained practically stagnant until the $75^{\text {th }}$ day and then increased until the end of evaluations.

The intercropping with the hyacinth bean resulted in a larger crown diameter increment of coffee trees in 2010 and a higher diameter increment accumulated in the two evaluated years (Table 4 and Figure 3B). The fertilizations of $50 \%$ and $100 \%$ dose did not influence the crown diameter of coffee trees in that same year. In both doses, the crown diameter increment in 2010 followed quadratic model with the increase of the intercropping period (Figure 3B), similar to the behavior in 2009.

Although all coffee trees grew in height and crown diameter in the evaluated period, the reduction of this growth when intercropped with jack bean (JB) can be attributed to the competition with the legume, since it showed rapid initial growth, flowered with about 70 days, thus initiating the production of pods and accumulating more mass than the hyacinth bean, as verified in Figure 1, which resulted in lower competition with the coffee tree. 
TABLE 4 - Height increment (cm) in 2010 at each intercropping period and in organic fertilizations of 50\% and $100 \%$ of the dose; diameter increment in 2010 (Diam 2010, cm) and accumulated diameter in 2009 and 2010 (Acc. diam, cm) of the coffee trees intercropped with jack bean and hyacinth bean for different periods of days after sowing (DAS).

\begin{tabular}{|c|c|c|c|c|c|c|c|c|}
\hline \multirow{3}{*}{ SPECIES } & \multicolumn{6}{|c|}{ HEIGHT 2010} & \multirow{3}{*}{$\begin{array}{l}\text { Diam } \\
2010^{1}\end{array}$} & \multirow{3}{*}{$\begin{array}{c}\text { Acc. } \\
\text { diam }\end{array}$} \\
\hline & \multicolumn{4}{|c|}{ Intercropping season' } & \multicolumn{2}{|c|}{ Fertilization $^{2}$} & & \\
\hline & 30 DAS & $60 \mathrm{DAS}$ & $90 \mathrm{DAS}$ & $120 \mathrm{DAS}$ & $50 \%$ & $100 \%$ & & \\
\hline Jack bean & $30.60 \mathrm{~A}$ & $27.25 \mathrm{~A}$ & $28.17 \mathrm{~A}$ & $31.67 \mathrm{~A}$ & $28.70 \mathrm{a} \mathrm{B}$ & $30.14 \mathrm{aA}$ & $11.05 \mathrm{~b}$ & $60.06 \mathrm{~b}$ \\
\hline Hyacinth bean & $23.97 \mathrm{~B}$ & $29.88 \mathrm{~A}$ & $32.14 \mathrm{~A}$ & $36.39 \mathrm{~A}$ & $32.18 \mathrm{a} \mathrm{A}$ & $29.01 \mathrm{aA}$ & $15.66 \mathrm{a}$ & $65.57 \mathrm{a}$ \\
\hline
\end{tabular}
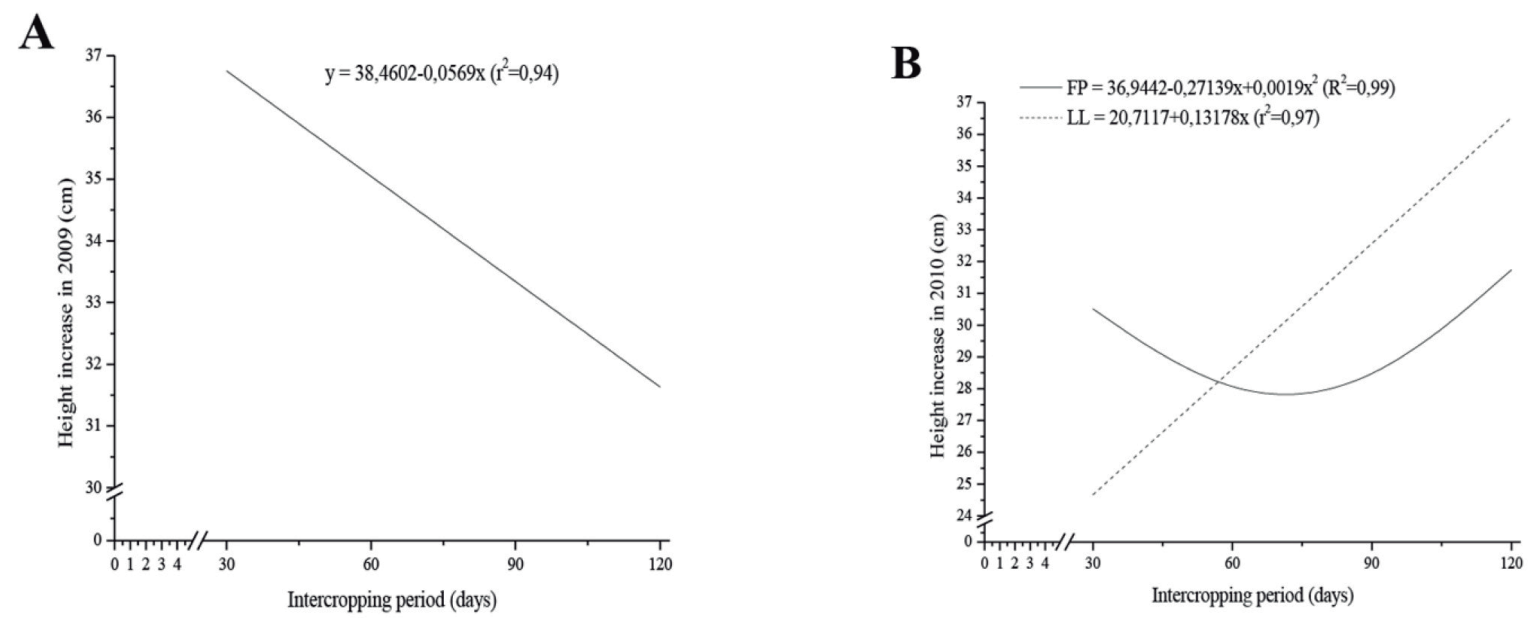

FIGURE 2 - Height increment in 2009 (A) and 2010 (B) of coffee trees, due to the species of intercropped green manure (jack bean and hyacinth bean) at each intercropping period..

Jack bean is a species of tropical and subtropical climate, adapted to practically all types of soils, being considered as very rustic, resistant to high temperatures and drought, with a long annual cycle of 180 days and flowering with approximately 140 days (BARRETO; FERNANDES, 2001). The ideal conditions of JB cultivation may have favored its early flowering.

Moreira et al. (2014) reported that intercropping with hyacinth bean resulted in different effects on adult coffee trees: the longer the intercropping period with the hyacinth bean, the higher the reduction of crown diameter in the $1^{\text {st }}$ year, however, in the $2^{\text {nd }}$ year, the longer the intercropping period with the hyacinth bean, the larger the crown diameter of coffee trees, similar to the result obtained with young coffee trees in this experiment. Such results suggest that miscellaneous effects can be expected in continuous evaluations for a higher number of years. Moreira et al. (2014) observed divergent results between the coffee intercropped with jack bean and hyacinth bean in relation to the intercropping period, the crown diameter of coffee trees was affected negatively by the increased conservation period with hyacinth bean, and the intercropping with jack bean resulted in linear response plateau model.

The legumes did not result in distinct effects on the number of nodes $(\mathrm{NN})$ of coffee trees, in none year $(p \geq 0.05)$. In 2009 , the $\mathrm{NN}$ increased linearly over time, with no significant difference as a function of the fertilization dose (Figure 4A). 
A

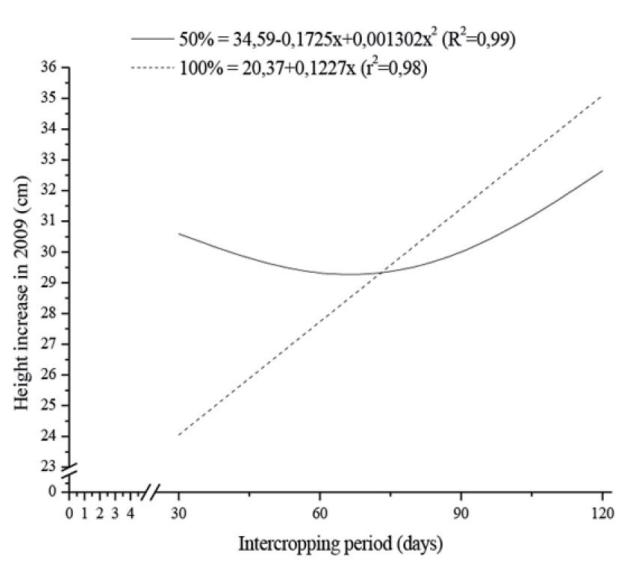

B



FIGURE 3 - Increment in height and crown diameter in 2010 of coffee plants under 50\% and $100 \%$ organic fertilization..

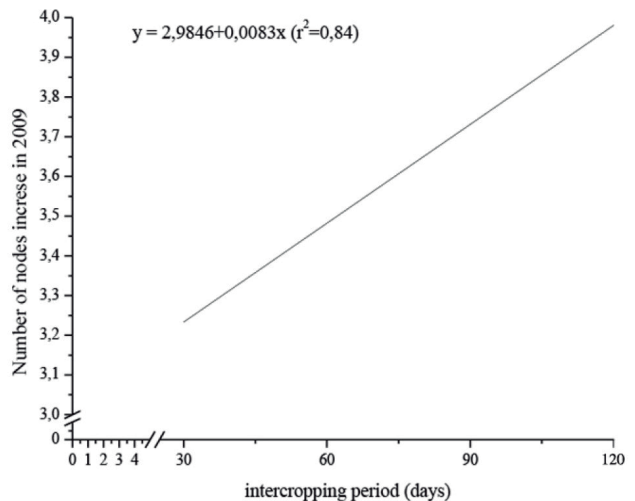

A - 2009

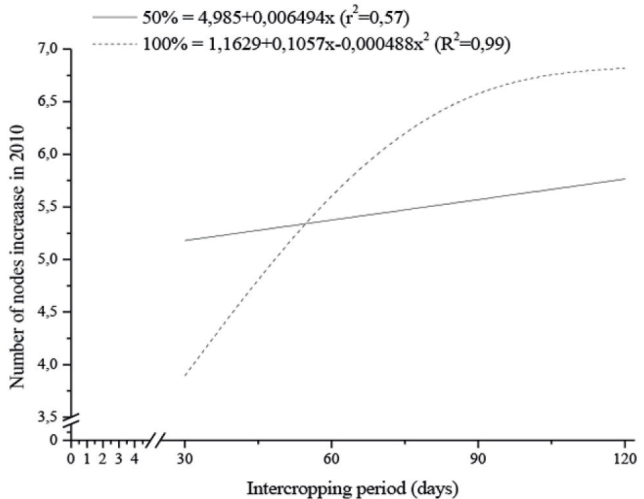

B - 2010

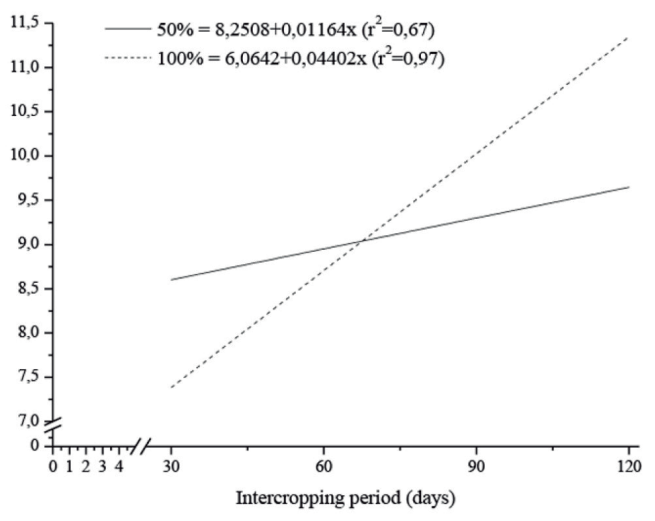

\section{C - Final}

FIGURE 4 - Increment in number of nodes in 2009 (A - average of two doses of fertilization), in 2010 (B) and final increment in the number of nodes (C) of coffee plants at each intercropping period with legumes and under $50 \%$ and $100 \%$ recommended fertilization. Averages of treatments from two intercropped legumes. 
Regarding the increase of NN in 2010, coffee plants fertilized with $50 \%$ dose showed a higher increase in the NN up to about 70 DAS, which was overcame by the coffee tree fertilized with $100 \%$ dose after this intercropping period (Figure 4B). The accumulated increment in the NN within two years was higher in coffee trees that received the full dose of fertilization (Figure 4C).

In a comparative study between the exclusive supply of biomass of feed peanut or mucuna, it was observed that the legumes showed stem perimeter, crown diameter, number of nodes and leaves similar with one another and higher than those fertilized with ammonium sulfate (VILELA et al., 2011). In another research the biomass of feed peanut promoted increases in crown diameter and volume, height and number of plagiotropic branches (FIDALSKI; CHAVES, 2010). Araújo et al. (2014) observed that initially $30 \%$ initial dose of the mineral fertilizer adequately nourished the coffee tree until the beginning of the reproductive period. However, at the end of this period, it became necessary to supplement the fertilization with $584 \mathrm{~g} \mathrm{plant}^{-1}$ of jack bean biomass. These results demonstrate the beneficial effect of applying legume biomass on the initial growth of the coffee tree. In any case, it should be emphasized that these studies did not deal with intercropping between coffee trees and green manures, but rather the supply of green mass to the coffee tree. Thus, there was no competition among plants.

Leaf NC in coffee plants analyzed at 30 and 150 DASL were influenced only by the intercropping period $(\mathrm{p}<0.05)$. There was no effect of the intercropping period or the species on the NC when coffee trees were evaluated at 60,90 and 120 DASL and compared with the average of controls (Table 5).

In the analysis performed at coffee plantation in 2008/2009, the NC increased little over time when the legumes were cut at 30 DASL (Figure 5A), which can be attributed to the residual effect of the matter of intercropped legumes in the two previous years. With the cut of legumes at 30 DASL, the intercropping between the coffee tree and the hyacinth bean for 60 and 120 days resulted in a higher average $\mathrm{NC}$ (Table 5), and the other treatments did not differ from the average of controls.

In coffee trees evaluated at 150 DASL in $2008 / 2009$ and 2009/2010 crop season, the N concentration increased linearly with the increase of the intercropping period, regardless of the legume species (Figures 5A and $\mathrm{B}$ ). This result can be explained by the increasing amount of mass and N (Figures 1B and 1D) of legumes supplied to the coffee trees.

TABLE 5 - Nitrogen concentrations (NC, \%) in the coffee tree at 30 and 150 days after sowing of legumes (DASL) jack bean and hyacinth bean cut at 30,60, 90 or 120 days and the average of controls $(50 \%$ and $100 \%$ fertilization), in the 2008/2009 crop season.

\begin{tabular}{cccc}
\hline SPECIES & DAYS OF INTERCROPPING & $\begin{array}{c}\text { NC 30 DASL } \\
(\%)\end{array}$ & $\begin{array}{c}\text { NC 150 DASL } \\
(\%)\end{array}$ \\
\hline Control & 30 & 2.49 & 3.16 \\
Jack bean & 60 & 2.58 & 3.05 \\
& 90 & 2.57 & 3.19 \\
& 120 & 2.65 & $3.54 \mathrm{~A}^{*}$ \\
Hyacinth bean & 30 & 2.74 & $3.61 \mathrm{~A}^{*}$ \\
\hline & 60 & 2.53 & 3.14 \\
& 90 & $2.76 \mathrm{~A}^{*}$ & 3.25 \\
\hline CV (\%) & 120 & 2.56 & $3.56 \mathrm{~A}^{*}$ \\
\hline
\end{tabular}

Averages followed by $*$ differ from the control by the Dunnett's test $(p<0.05)$. 


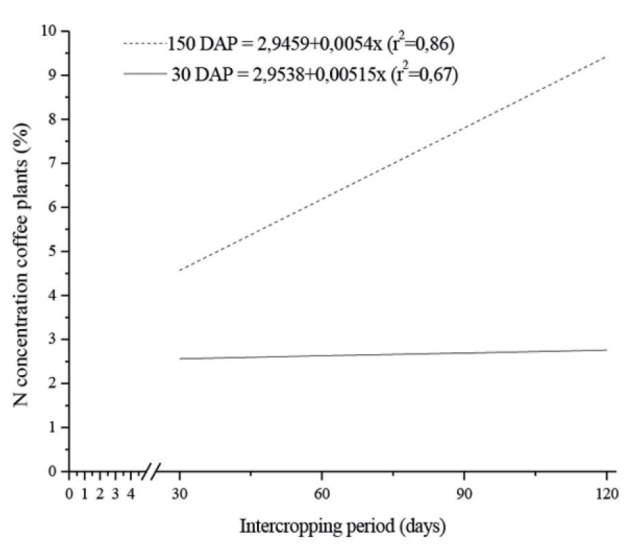

A - 2008/2009

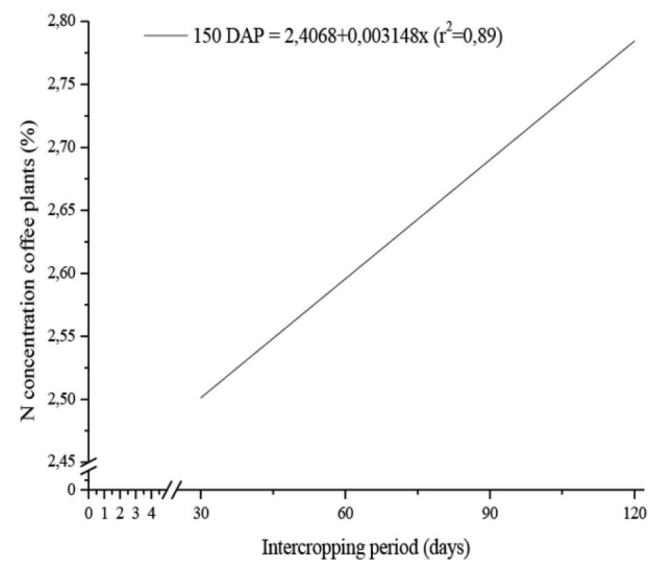

B - 2009/2010

FIGURE 5 - Leaf nitrogen concentration (NC, \%) in the coffee tree after 30 and 150 days after sowing (DAD) of green manures at each intercropping period with legumes (30, 60, 90 and 120 DASL) in the 2008/2009 and 2009/2010 crop season.

In the 2008/2009 crop season, in the evaluation of $30 \mathrm{DASL}$, the coffee trees presented $\mathrm{NC}$ similar to the average of controls (50 and $100 \%$ ) without intercropping (Table 5). In the same year $(2008 / 2009)$ at 150 DASL, the coffee trees intercropped with the jack bean for 90 and 120 days and with the hyacinth bean for 90 days showed higher NC in relation to the other intercropping periods and the average of controls (Table 5). These concentrations were above the low level of $<2.50 \mathrm{dag} \mathrm{kg}^{-1}$, established for the coffee tree (GUIMARÃES et al., 1999). Legume cutting at 30 DASL resulted in low mass and $\mathrm{N}$ accumulation, i.e., the short intercropping period provided little or no effect on $\mathrm{NC}$ of coffee trees evaluated at 30 DASL. However, in the evaluation at 150 DASL, the effects of increased amounts of mass and $\mathrm{N}$ provided due to the longer intercropping period, and the longer time of mineralization and uptake of $\mathrm{N}$ by coffee trees, resulted in higher $\mathrm{NC}$ in the tissues.

In the 2008/2009 crop season, the coffee trees showed $\mathrm{NC}$ within the aforementioned range considered as adequate for the region and in values similar or superior to the control without intercropping. The increased NC at the end of the reproductive cycle (150 DASL) when compared with the beginning of the cycle (30 DASL) in the different intercropping periods suggests that the soil supply and $\mathrm{N}$ uptake by the roots were sufficient to meet the demands of fruits and leaves. These results suggest a possible lack of competition of the green manure with the coffee tree by nitrogen, besides reflecting the positive effect of intercropped legumes in 2007/2008 crop season.

In $2009 / 2010$, for the leaf $\mathrm{N}$ of the coffee tree, there was only a significant effect of the interaction species $\mathrm{x}$ intercropping period and fertilization $\mathrm{X}$ intercropping period (Figure $5 \mathrm{~B}$ and Table 6). There was no effect of treatments when coffee trees were evaluated at 60,90 and 120 days. In the evaluation of coffee trees at 30 DASL, those intercropping with JB had higher NC than those intercropped with hyacinth bean (HB), which was reversed when the coffee trees were evaluated at 150 DASL (Table 6). In both evaluation dates, the coffee trees that received the full-dose fertilization showed higher NC (Table 6).

This result is explained by the mass decomposition and accelerated $\mathrm{N}$ mineralization of the $\mathrm{HB}$ in relation to the JB, possibly because the JB is a shorter cycle plant with pod formation and a higher lignin content as early as 70 days (BARRETO; FERNANDES, 2001), whereas the $\mathrm{HB}$ no flowering was observed until the last cutting date.

The leaf tissue analysis of coffee trees at 26 days after the final cut of the crotalaria showed that in the plots where the legume was cultivated, there was a significant reduction of the accumulated total $\mathrm{N}$ concentration, from 2.93 (May/2002) to 3.5 before the crotalaria cultivation (November/2001), being kept below the level considered as critical (3\%), possibly due to the greater competition exerted by the legume throughout its development, by the $\mathrm{N}$ available in the soil (RICCI et al., 2005). 
TABLE 6 - Leaf nitrogen concentration (NC, \%) in the coffee tree at 30 and 150 days after the sowing (DASL) of green manures jack bean and hyacinth bean (DASL), and with $50 \%$ and $100 \%$ of the recommended fertilization in the $2009 / 2010$ crop season.

\begin{tabular}{|c|c|c|c|}
\hline \multirow{2}{*}{\multicolumn{2}{|c|}{ Variable }} & \multicolumn{2}{|c|}{$\mathrm{NC}(\%)$} \\
\hline & & 30 DASL & 150 DASL \\
\hline \multirow{2}{*}{ Species } & Jack bean & $2.79 \mathrm{a}$ & $2.58 \mathrm{~b}$ \\
\hline & Hyacinth bean & $2.70 \mathrm{~b}$ & $2.70 \mathrm{a}$ \\
\hline \multirow{2}{*}{ Fertilization } & $50 \%$ & $2.68 \mathrm{~b}$ & $2.61 \mathrm{~b}$ \\
\hline & $100 \%$ & $2.81 \mathrm{a}$ & $2.68 \mathrm{a}$ \\
\hline
\end{tabular}

In order to evaluate the effect of species and fertilization, the averages followed by the same letter on the column do not differ among themselves by $\mathrm{F}$ test $(\mathrm{p} \geq 0.05)$.

Productivity was influenced only by the intercropping period, while the average biennial productivity was influenced only by fertilization $(\mathrm{p}<0.05)$. The productivity of 2010 decreased in a quadratic way due to the increase in the intercropping period with legumes. In 2011, the result was inverse showing a quadratic increase with the increased intercropping period (Figure 6). The average biennial productivity of the coffee trees subjected to $100 \%$ fertilization exceeded the productivity of coffee trees that received only $50 \%$ of the recommended fertilization, showing 15.422 and $13.906 \mathrm{bg} \mathrm{ha}^{-1}$, respectively.

The yield and productivity of coconut coffee, as well as that of beans harvested in 2010 and the yield of coffee beans in 2011 did not differ statistically from the control fertilized with $50 \%$ of the recommended dose ( $\mathrm{p} \geq 0.05)$, regardless of the intercropped legume, intercropping period or fertilization dose.

When evaluated in 2010, the coconut coffee, processed beans and productivity and, in 2011, the processed bean, yield and productivity, besides the average biennial productivity, did not differ statistically from the control at $50 \%$ of the recommended dose $(\mathrm{p} \geq 0.05)$, regardless of the intercropped legume, intercropping period or fertilization dose (Table 7). These results indicate that the legumes supplied the nutritional requirements of coffee trees fertilized with $50 \%$ dose, when compared with the control that received $100 \%$ fertilization.

Regarding the coffee yield, there was a difference for the green manure factor analyzed separately for the yield obtained in the first stage of the harvest, being that the yield obtained in the absence of green manure was significantly higher than that obtained in its presence, although there was no difference in the final yield (sum of the two steps). The lack of response of the coffee tree in relation to the yield obtained with and without the cultivation of green manure between the lines can be considered as a positive result, since it allows concluding that the cultivation of a green manure associated with the coffee tree did not hindered its yield.

When evaluating the yield in 2010 , the $100 \%$ control exceeded the intercropping with jack bean at 120 days fertilized with only $50 \%$ of the recommended dose, which is $37.78 \%$. Coconut coffee in 2011 presented a significance difference between the $100 \%$ control and the intercropping with the hyacinth bean 120 days with $100 \%$ dose fertilization, showing average of $2,536.63 \mathrm{~kg} \mathrm{ha}$ ${ }^{1}$, higher than the $890.05 \mathrm{~kg} \mathrm{ha}^{-1}$ of the control (Table 7).

These results demonstrate the low achieved yields, including controls fed with 50\% and $100 \%$ of the recommended fertilization, which did not differ from the other treatments, except jack bean intercropped for 120 days and fertilized with $50 \%$ of the recommended dose in 2010 when compared to the $100 \%$ fertilized control (Table 7). Possibly, the low yield was due to the strong drought together with high temperatures during the months of January and February 2010, period of grain formation, which affected the productivity initially expected (60 bg ha ${ }^{-1}$, based on a preliminary evaluation in the edges), due to the higher incidence of malformed, immature and defective fruits, increasing the ratio of in natura fruits necessary to obtain a processed bag of coffee. Furthermore, the drier climate in the months of August and September 2009 caused premature maturation of the beans (harvest in March and April 2010), further compromising the grain formation process, evidenced by the low yield achieved in 2010 . 


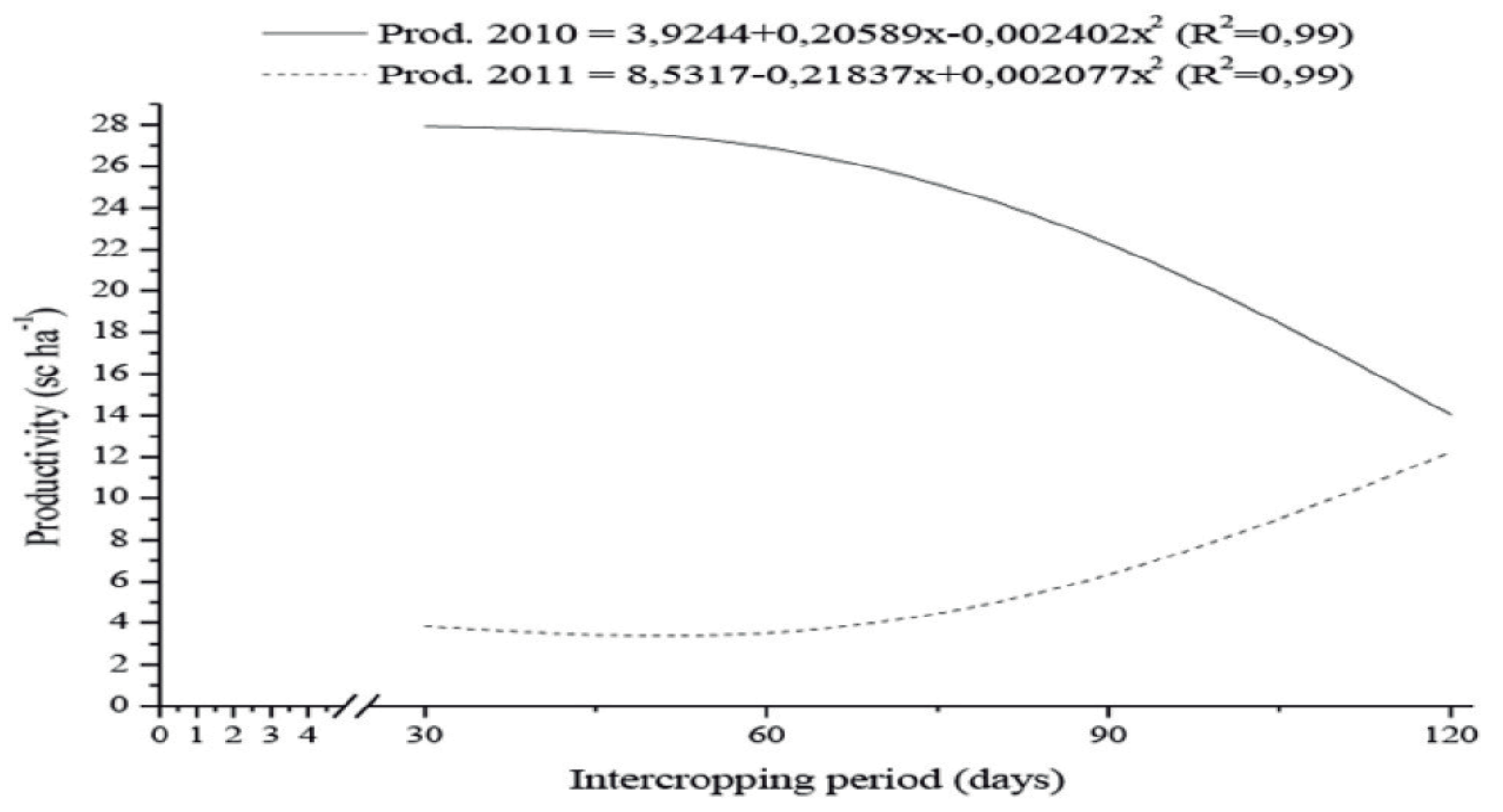

FIGURE 6 - Productivity of coffee plants as a function of intercropping with legumes for different periods (30, 60, 90 and 120 days after showing of the legume) in the crop season 2009/2010 (Prod. 2010) and 2010/2011 (Prod. 2011). Data from two species of legumes and two fertilization doses.

In the literature, there are contradictory reports of the effect of organic fertilization on the productivity of coffee trees, e.g., Malta et al. (2007) observed increase from 33 to 40.8 bg ha ${ }^{-1}$ with pigeon pea, as well as observed by Araujo et al. (2014) with the jack bean. Theodoro, Mendes and Guimarães (2009) verified that coffee productivity was not influenced by applying this legume. However, Moreira et al. (2014) observed that productivity was reduced in the first year for both the jack bean and the hyacinth bean in all evaluated periods, and in the second year, only the intercropping with jack bean for 120 days resulted in reduced coffee productivity. In some cases, the lower productivities were attributed to the greater competition for water, light and nutrients between the legumes and the coffee tree due to the higher matter yield of legumes.

The low productivity in the 2011 harvest was probably affected not only by the negative biennial of coffee, but also due to the severe drought suffered by the crop from the beginning of April 2010, when there is the maturation and bud development phase (April to June). The coffee plantation received below-average rainfall volumes for more than five months, which contributed to a greater leaf fall of plants.

Plants with low leaf area indexes tend to have low yields due to the high abortion rate of pinheads. One hypothesis for higher productivity in 2011 in the 120-day intercropping would be to maintain soil moisture due to green manure cutting and higher soil mulch under coffee plantation. In a research on the nitrogen efficiency fertilization in the intercropping between coffee tree and brachiaria, it was observed that the maintenance of the brachiaria biomatter under the crown of the coffee tree reduced the water loss in the dry months by $49 \%$, favoring the development of cultivated plants (PEDROSA, 2013).

The higher soil mulch increased root density and maintained moisture and hence higher nutrient recovery efficiency, due to the higher yield of surface roots in the coffee trees that received brachiaria biomatter in relation to the control, and a higher recovery of ${ }^{15} \mathrm{~N}$ by the coffee tree that received the brachiaria biomatter fertilized with $50 \%$ of the recommended dose to the coffee tree (PEDROSA, 2013). 
TABLE 7 - Coconut coffee $\left(\mathrm{CC}, \mathrm{t} \mathrm{ha}^{-1}\right)$, processed bean (PB, $\left.\mathrm{t} \mathrm{ha}^{-1}\right)$, yield (Yld, \%), productivity $\left(\mathrm{Pr}\right.$, bg ha $\left.{ }^{-1}\right)$ and average biennial productivity (AvBProd, $\mathrm{bg} \mathrm{ha}^{-1}$ ) in the coffee tree fertilized with $100 \%$ and $50 \%$ fertilization, intercropped with jack bean (JB) and hyacinth bean (HB) under four cutting seasons (30, 60, 90 and 120 DASL) in the 2009/10 and 2010/11 crop season.

\begin{tabular}{|c|c|c|c|c|c|c|c|c|c|c|c|}
\hline SPC & MAN & $\begin{array}{c}\text { FERT } \\
\%\end{array}$ & $\begin{array}{c}\text { CC2010 } \\
\text { t ha }^{-1}\end{array}$ & $\begin{array}{c}\text { PB2010 } \\
\text { t ha }^{-1}\end{array}$ & $\begin{array}{c}\text { Yld2010 } \\
\%\end{array}$ & $\begin{array}{l}\text { Pr2010 } \\
\text { bg ha }{ }^{-1}\end{array}$ & $\begin{array}{c}\text { CC2011 } \\
\text { t ha }^{-1}\end{array}$ & $\begin{array}{c}\text { PB2011 } \\
\mathrm{t} \mathrm{ha}^{-1}\end{array}$ & $\begin{array}{c}\text { Yld2011 } \\
\%\end{array}$ & $\begin{array}{l}\text { Pr2011 } \\
\text { bg ha- }^{-1}\end{array}$ & $\begin{array}{c}\text { AvPBrod } \\
\text { bg ha- }\end{array}$ \\
\hline Test & & 100 & $3.72 \mathrm{~A}$ & $1.40 \mathrm{~A}$ & $37.78 \mathrm{~A}$ & $23.41 \mathrm{~A}$ & $0.89 \mathrm{~A}$ & $0.29 \mathrm{~A}$ & $34.53 \mathrm{~A}$ & $\mathrm{~A} \quad 4.93 \mathrm{~A}$ & $14.17 \mathrm{~A}$ \\
\hline Test & & 50 & $3.53 \mathrm{~A}$ & $1.04 \mathrm{~A}$ & $30.66 \mathrm{~A}$ & $17.26 \mathrm{~A}$ & $0.58 \mathrm{~A}$ & $0.20 \mathrm{~A}$ & $35.39 \mathrm{~A}$ & A $3.31 \mathrm{~A}$ & $10.28 \mathrm{~A}$ \\
\hline \multirow{8}{*}{ JB } & 30 & 50 & $3.49 \mathrm{~A}$ & $1.37 \mathrm{~A}$ & $38.85 \mathrm{~A}$ & $22.80 \mathrm{~A}$ & $0.68 \mathrm{~A}$ & $0.29 \mathrm{~A}$ & $36.08 \mathrm{~A}$ & $\mathrm{~A} \quad 4.80 \mathrm{~A}$ & $13.80 \mathrm{~A}$ \\
\hline & 60 & 50 & $4.04 \mathrm{~A}$ & $1.44 \mathrm{~A}$ & $35.67 \mathrm{~A}$ & $24.07 \mathrm{~A}$ & $0.37 \mathrm{~A}$ & $0.13 \mathrm{~A}$ & $36.59 \mathrm{~A}$ & A $2.14 \mathrm{~A}$ & $13.10 \mathrm{~A}$ \\
\hline & 90 & 50 & $4.09 \mathrm{~A}$ & $1.56 \mathrm{~A}$ & $37.59 \mathrm{~A}$ & $26.03 \mathrm{~A}$ & $0.49 \mathrm{~A}$ & $0.16 \mathrm{~A}$ & $34.53 \mathrm{~A}$ & A $2.66 \mathrm{~A}$ & $14.35 \mathrm{~A}$ \\
\hline & 120 & 50 & $3.16 \mathrm{~A}$ & $0.63 \mathrm{~A}$ & 18.38 B & $10.45 \mathrm{~A}$ & $1.69 \mathrm{~A}$ & A $\quad 0.59 \mathrm{~A}$ & $34.93 \mathrm{~A}$ & A $9.91 \mathrm{~A}$ & $10.18 \mathrm{~A}$ \\
\hline & 30 & 100 & $5.08 \mathrm{~A}$ & $1.90 \mathrm{~A}$ & $37.00 \mathrm{~A}$ & $31.67 \mathrm{~A}$ & $0.99 \mathrm{~A}$ & $0.39 \mathrm{~A}$ & $37.32 \mathrm{~A}$ & $\mathrm{~A} 6.52 \mathrm{~A}$ & $19.10 \mathrm{~A}$ \\
\hline & 60 & 100 & $4.00 \mathrm{~A}$ & $1.21 \mathrm{~A}$ & $29.30 \mathrm{~A}$ & $20.12 \mathrm{~A}$ & $0.76 \mathrm{~A}$ & $0.26 \mathrm{~A}$ & $34.47 \mathrm{~A}$ & A $4.29 \mathrm{~A}$ & $12.21 \mathrm{~A}$ \\
\hline & 90 & 100 & $3.94 \mathrm{~A}$ & $1.54 \mathrm{~A}$ & $37.93 \mathrm{~A}$ & $25.70 \mathrm{~A}$ & $1.36 \mathrm{~A}$ & A $\quad 0.45 \mathrm{~A}$ & $34.39 \mathrm{~A}$ & A $7.46 \mathrm{~A}$ & $16.58 \mathrm{~A}$ \\
\hline & 120 & 100 & $2.69 \mathrm{~A}$ & $0.91 \mathrm{~A}$ & $33.50 \mathrm{~A}$ & $15.18 \mathrm{~A}$ & $1.95 \mathrm{~A}$ & $0.73 \mathrm{~A}$ & $36.99 \mathrm{~A}$ & A $12.19 \mathrm{~A}$ & $13.68 \mathrm{~A}$ \\
\hline \multirow{8}{*}{$\mathrm{HB}$} & 30 & 50 & $4.42 \mathrm{~A}$ & $1.67 \mathrm{~A}$ & $37.82 \mathrm{~A}$ & $27.87 \mathrm{~A}$ & $0.42 \mathrm{~A}$ & $0.17 \mathrm{~A}$ & $36.64 \mathrm{~A}$ & A $2.81 \mathrm{~A}$ & $15.34 \mathrm{~A}$ \\
\hline & 60 & 50 & $4.60 \mathrm{~A}$ & $1.88 \mathrm{~A}$ & $39.60 \mathrm{~A}$ & $31.31 \mathrm{~A}$ & $0.60 \mathrm{~A}$ & $0.20 \mathrm{~A}$ & $34.03 \mathrm{~A}$ & A $3.34 \mathrm{~A}$ & $17.32 \mathrm{~A}$ \\
\hline & 90 & 50 & $3.54 \mathrm{~A}$ & $1.25 \mathrm{~A}$ & $35.47 \mathrm{~A}$ & $20.75 \mathrm{~A}$ & $1.03 \mathrm{~A}$ & $0.39 \mathrm{~A}$ & $39.49 \mathrm{~A}$ & A $\quad 6.57 \mathrm{~A}$ & $13.66 \mathrm{~A}$ \\
\hline & 120 & 50 & $2.26 \mathrm{~A}$ & 1 $081 \mathrm{~A}$ & $33.67 \mathrm{~A}$ & $13.42 \mathrm{~A}$ & $2.08 \mathrm{~A}$ & $\mathrm{~A} \quad 0.81 \mathrm{~A}$ & $35.47 \mathrm{~A}$ & $\mathrm{~A} 13.54 \mathrm{~A}$ & $13.48 \mathrm{~A}$ \\
\hline & 30 & 100 & $4.79 \mathrm{~A}$ & $1.82 \mathrm{~A}$ & $37.92 \mathrm{~A}$ & $30.39 \mathrm{~A}$ & $2.15 \mathrm{~A}$ & A $\quad 0.70 \mathrm{~A}$ & $36.34 \mathrm{~A}$ & A $1.16 \mathrm{~A}$ & $15.77 \mathrm{~A}$ \\
\hline & 60 & 100 & $4.69 \mathrm{~A}$ & $1.93 \mathrm{~A}$ & $40.67 \mathrm{~A}$ & $32.09 \mathrm{~A}$ & $3.75 \mathrm{~A}$ & A $\quad 0.13 \mathrm{~A}$ & $34.43 \mathrm{~A}$ & A $2.14 \mathrm{~A}$ & $17.11 \mathrm{~A}$ \\
\hline & 90 & 100 & $3.66 \mathrm{~A}$ & $1.35 \mathrm{~A}$ & $36.61 \mathrm{~A}$ & $22.44 \mathrm{~A}$ & $0.89 \mathrm{~A}$ & A $\quad 0.35 \mathrm{~A}$ & $39.51 \mathrm{~A}$ & A $5.83 \mathrm{~A}$ & $14.13 \mathrm{~A}$ \\
\hline & 120 & 100 & $2.63 \mathrm{~A}$ & $0.97 \mathrm{~A}$ & $34.48 \mathrm{~A}$ & $16.14 \mathrm{~A}$ & $2.54 \mathrm{~B}$ & $0.80 \mathrm{~A}$ & $33.97 \mathrm{~A}$ & A $13.40 \mathrm{~A}$ & $14.77 \mathrm{~A}$ \\
\hline Averages & & & 3.81 & 1.39 & 35.43 & 23.17 & 1.02 & 0.37 & 35.86 & 6.10 & 14.64 \\
\hline $\mathrm{CV}(\%)$ & & & 22.36 & 31.70 & 17.30 & 31.70 & 69.23 & 77.72 & 15.67 & 77.72 & 27.01 \\
\hline
\end{tabular}

Averages followed by the same letter on the column do not differ from the control by Dunnett's test ( $\mathrm{p} \geq 0.05$ ).

\section{CONCLUSIONS}

The jack bean overcomes the hyacinth bean in the yield of fresh and dry matter, $\mathrm{N}$ concentration and $\mathrm{N}$ accumulation.

The increased intercropping period between legumes and coffee trees favors a greater increase in height and the number of nodes of the coffee plants.

The coffee trees show higher heights when fertilized with $50 \%$ of the recommended dose and intercropped with hyacinth bean.

The intercropping with hyacinth bean resulted in a larger crown diameter of coffee trees in 2010 and a larger diameter accumulated in the two evaluated years.

The leaf $\mathrm{N}$ concentration at the end of the reproductive cycle (150 DASL) is higher in relation to the beginning of the cycle (30 DASL) for the different intercropping periods.

Higher $\mathrm{N}$ contents are found in coffee trees fertilized with $100 \%$ of the recommended dose.

The legumes supplement and supply the nutrients required in the harvest of coffee fertilized with $50 \%$ dose.

The bean yield of the processed coffee tree is not hindered by the intercropping with the green manures jack bean or hyacinth bean.

\section{REFERENCES}

AMARAL, J. F. T. et al. Eficiência da utilização de nutrientes por cultivares de cafeeiro. Ciência Rural, Santa Maria, v. 41, n. 4, p. 621-629, abr. 2011. 
ARAUJO, J. B. S. et al. Adubação nitrogenada em cafeeiros com biomatéria de feijão de porco. Coffee Science, Lavras, v. 9, n. 3, p. 336-346, jul./set. 2014.

BARRETO, A. C.; FERNANDES, M. F. Recomendações técnicas para o uso da adubação verde em solos de Tabuleiros Costeiros. Aracaju: EMBRAPA Tabuleiros Costeiros, 2001. 24 p. (Embrapa Tabuleiros Costeiros, Circular Técnica, 19).

COTTA, O. et al. Validação do método para determinação de nitrogênio kjeldahl total. Revista Analytica, Rio de Janeiro, v. 26, n. 1, p. 68-75, 2007.

FENILLI, T. A. B. et al. Fertilizer $15 \mathrm{~N}$ balance in a coffee cropping system: a case study in Brazil. Revista Brasileira de Ciência do Solo, Viçosa, v. 32, p. 14591469, 2008.

FIDALSKI, J.; CHAVES, J. C. D. Respostas do cafeeiro (Coffea arabica L.) IAPAR-59 à aplicação superficial de resíduos orgânicos em um latossolo vermelho distrófico típico. Coffee Science, Lavras, v. 5, n. 1, p. 75-86, jan./abr. 2010.

FUNDAÇÃO ARTHUR BERNARDES. SAEG Sistema para Análises Estatísticas. Versão 9.1. Viçosa, MG: Ed. UFV, 2007.

GUIMARÃES, P. T. G. et al. Cafeeiro. In: RIBEIRO, A. C.; GUIMARÃeS, P. T. G.; AlvareZ, V. H. (Ed.). Recomendações para o uso de corretivos e fertilizantes em Minas Gerais: $5^{\text {a }}$ aproximação. Viçosa, MG: CSFSEMG/UFV, 1999. p. 289-302.

ILANY, T. et al. Using agroforestry to improve soil fertility: effects of intercropping on Ilex paraguariensis (yerba mate) plantations with Araucaria angustifolia. Agroforest Systems, Wageningen, v. 80, n. 3, p. 399409, 2010.
MALTA, M. R. et al. Produtividade de lavouras cafeeiras em conversão para o sistema de produção orgânico. Coffee Science, Lavras, v. 2, n. 2, p. 183191, 2007.

MOREIRA, G. M. et al. Consorciação em cafeeiros orgânicos por diferentes períodos com feijão-de-porco ou lablabe. Coffee Science, Lavras, v. 9, n. 4, p. 456464, out./dez. 2014.

PEDROSA, A. W. Eficiência da adubação nitrogenada no consórcio entre cafeeiro e Brachiaria brizantha. 2013. 73 p. Tese (Doutorado em Ciências)Escola Superior de Agricultura "Luiz de Queiroz", Piracicaba, 2013.

PEDROSA, A. W. et al. Resíduo de Brachiaria fertilizada com nitrogênio na adubação do cafeeiro. Coffee Science, Lavras, v. 9, n. 3, p. 366-373, jul./set. 2014.

RICCI, M. S. F. et al. Growth rate nutricional status of na organic coffee cropping system. Scientia Agricola, Piracicaba, v. 62, n. 2, p. 138-144, 2005.

THEODORO, V. C. A.; MENDES, A. N. G.; GUIMARÃES, R. J. Resposta de lavouras cafeeiras em transição agroecológica a diferentes manejos do solo. Coffee Science, Lavras, v. 4, n. 1, p. 56-66, 2009.

TORRES, J. L. R.; PEREIRA, M. G.; FABIAN, A. J. Produção de fitomatéria por plantas de cobertura e mineralização de seus resíduos em plantio direto. Pesquisa Agropecuária Brasileira, Brasília, DF, v. 3, p. 421-428, 2008.

VILELA, E. F. et al. Crescimento inicial de cafeeiros e fertilidade do solo adubado com mucuna, amendoim forrageiro ou sulfato de amônio. Coffee Science, Lavras, v. 6, n. 1, p. 27-35, jan./abr. 2011. 